\title{
On the Problem of Evolution \\ of the Russian Orthodox Church's Missionary Activity in the XVIII - 60-s of the XIX Centuries
}

\author{
Valentina N. Asochakova* \\ Katanov Khakass State University \\ 18 Druzhby Narodov Str., Abakan, Khakassia, 655016, Russia
}

Received 04.06.2014, received in revised form 20.09.2014, accepted 05.10.2014

\begin{abstract}
Christianization of the indigenous peoples of Siberia was of a general nature. It had a common legal basis for two centuries. Public arrangements of the Soviet power were characterized by a moderate attitude to mass baptism and tolerance to existing religious beliefs of the natives. These general aims were corrected by the Russian Orthodox Church the structure of which was formed on the basis of narrow departmental interests to speed up Christianization. This article reviews the reforms of the missionary activity in the XVIII - the first quarter of the XIX centuries, aiming at the transition from formal baptism to consolidation of Christianization and Russianization of other peoples. The autochthonous population of the Khakass-Minusinsk territory served the example for the analysis of its forms, methods of baptism and quantitative indicators of baptism. The vested system of missionary activity could not solve political and ideological tasks of assimilation of the indigenous population of Siberia, integration of a multi-confessional multilingual social space of the Russian Empire and needed radical changes. The source base is presented by documentation and sources of church demographic statistics.
\end{abstract}

Keywords: christianization, Russian Orthodox Church's missionary activity, tolerance, newly baptized people.

Research area: History.

Christianization of the indigenous peoples of Siberia was a part of the public policy in Siberia, aiming at the assimilation of the indigenous peoples and their disintegration in the Russian Orthodox society. The Russian Orthodox Church did not take into account natural geographic, economic-and-cultural types and other features of such regions as Northern and Western Siberia, Buryatia, two metallurgic districts, the territories' bordering position, while the Soviet power declared them.

Adhering to general periodization of the Russian state's internal policy in Siberia, the stages of Christianization of the indigenous peoples of Siberia can be distinguished in accordance with the evolution of forms and methods of missionary activity. The nature and essence of each stage can be defined by a complex assessment of the results.

(C) Siberian Federal University. All rights reserved

* Corresponding author E-mail address: asocvn@mail.ru 
There are some stages in the state policy of Christianization in Siberia, including the KhakasMinusinsk region:

The first stage, the XVII century - the primary acquaintance with the Orthodox faith due to the communication with the Russian Cossacks and field men.

The second stage, 1700-1764 - the lack of common principles, forms and methods. Christening was exercised mainly in the form of the missionary activity, violent methods prevailed. The system of institutions, methods, instructions was developed for the missioners; the status of newly baptized people was formalized.

The third stage, 1764-1799 - the diocesan missionary,proclamation of thetoleranceprinciple; the means of Christianization are economic, legislative, administrative, social, organizational, and financial, while the educational means were on the second place.

The fourth stage, 1800-1825 - the parish phase of the missionary activity; the development of nonreligious methods of Christianization, the refusal to the mass christening policy, performing services in remote areas, organization of missions and ambulatory churches.

The fifth stage, 1764-1799 - the search for forms and methods of the missionary activity, the empire, the transition to the russification and assimilation policy.

At the last third of the XVIII century the 1860 -s of the XIX century the principle of tolerance became legislatively established in the Russian state's confessional policy. It was manifested in a loyal attitude to heterodox religions and recognition of their right to existence: the Muslims were granted freedom of religion; they were allowed to build mosques and open religious schools. In relation to the religious beliefs of the indigenous peoples of Siberia the change of imperial policy involved a shift from the forced ways of Christianization to the struggle with the displays of heathenism. In general, the tolerance policy was directed towards the solution of such problem as an organic inclusion of the population of outlying districts into the Russian Empire. The Russian Orthodox Church played an important role in overcoming the disintegration of various ethno-social structures and removing the differences between the local and the Russian Orthodox variants of culture. Historically, the process of orthodoxy moving to Siberia was going on directly under the control of the government, which was not interested in a religious confrontation of shamanism, Islam and Buddhism-Lamaism, co-existing on the territory.

From Catherine's time both society and church powers realized the necessity of reconsideration of the missionary case. However, the high church hierarchs' contradictory and even negative attitude to the tolerance policy had been observed for the whole period of time. Filofei Ornatsky mentioned that in Russia there appeared peculiar views on the missionary case as an exclusive case of the church; people began to talk that the governmental authorities' interference in the case of conversion of heathens into Christians was unjust as it drew to the violation of tolerance rules, and it was necessary to give the opportunity to the people of any belief, including the heathen one, to live as they wanted. In Ornatsky's opinion, being implemented in the non-Siberian people's attitude, such views, even still complicated, led to a lasting success of Christian propagation. The author supposed that it was necessary to join the efforts of the church and the government for Christianization of the native peoples of Siberia.

Reformation of the missionary activity in the $1^{\text {st }}$ half of the XIX century was carried out in several directions. Firstly, they established the system of institutions. They found a special department. It was the spiritual ministry with informative and supervisory functions. 
Documentation on the matters of belief was handed over to the spiritual consistories, those of secular cases - over to the province offices. The vertical system of supervision, beginning with the highest level of the state authority (the State Council, the Senate, the Cabinet of Ministers, the Ministry of Internal Affairs) and ending with local governing authorities, was built. Secondly, new forms and methods of the missionary work were devised. The conversion from the mass baptism policy to the establishment of Orthodoxy in distant places took place, field churches were found. The study of native Siberian languages was included in the priests' special training. Since 1803 the attempts to translate the principles of the Christian belief into the languages of Siberian people were made. Since 1814 and during the following 10 years the translations of the New Testament into Chuvash, Tatar, Mordvinian, Zyriansky, Votiatsky, and Karelian appeared. The missions for spreading Christianity among non-orthodox population were organized: in 1815 they organized the missionaries' camp in Irkutsk eparchy, in 1824 in Arkhangelsk eparchy. Thirdly, the elements of education were introduced into the missionary work: they built schools for the children of the native people of Siberia, taught vernacular (mother tongues). In 1812 the Biblical community was created to spread the Holy Writ among the foreigners and non-Russians.

In the "Regulations of the governance over the non-Siberian people" the principle of tolerance was confirmed and concretized. In $\S 286$ it was said that "non-Siberian people, who do not profess the Christian belief, have freedom to exercise divine services in accordance with their rules and traditions". Article 98 legalized the organization of "proper places for praying away from the churches". In Chapter $11 \S 291$ it was prohibited to incur any penalties on newly-baptized Christians "if they, while professing Christianity, neglect the church ceremonies because of their ignorance.
The only decent measures in this case are suggestions or persuasions". Marriages between the baptized and the non-baptized, "ceremonies peculiar to each religion" - heathen and Christian ones - were allowed. It was prohibited to carry on any missionary campaign without a permission of police or tribal heads.

In the $2^{\text {nd }}$ half of the XIX century the turn to special missions with the purpose of parish priests' liberation from burdensome duties and the qualified preachers' training was planned in Christianization. The legislative registration of the newly-baptized Christians' law status was in process: they were exempted from yasak (tribute) for three years (the decrees of 1826 and 1831). The part of yasak (tribute) was deducted from the sum stated in yasak tax book (1830). In 1834 they adopted the law, according to which a newlybaptized spouse could dissolve a marriage if the other spouse was of a different faith. In 1837 any rewards, which were given by the government to newly-baptized people starting from the XVII century, were cancelled. Some benefits were introduces in criminal legislation: in case of committing certain crimes such as "pilfering, quarrels, fights, etc." the newly-baptized people evaded penalties (Mavlutova, 2001).

It is worth while considering the influence of changes in confessional policy on the spreading of Orthodoxy in the Khakass-Minusinsk region. During the first twenty years of the XIX century Christianization of native inhabitants was of an occasional character. The parish priests rarely converted the parishes, wandering on the territory, to Orthodoxy. There are only a few registers about the newly-baptized. But still, their analysis makes it possible to note that during the $1^{\text {st }}$ quarter of the XIX century the average age of baptized people decreased up to 19,7. It was much lower than the average indicator in the XVIII century. The use of the church demographical registration sources makes it possible to considerably specify the 
number of the newly-baptized Khakass people in absolute and relative indices. In the table below there are data on the number of the newlybaptized Christians according to the confession registration.

Its analysis showed that from the last third of the XVIII century up to 1823 the Christianization rate was still decreasing and there was a steady tendency of decreasing of a newly-baptized part rather than of the autochthons' total number. By the end of the $1^{\text {st }}$ quarter of the XIX century 6241 people were baptized $-29,46 \%$ - i.e. the part of the baptized people from the total number decreased by 3,24\% during the period of 28 years. The native population grew up to 4806 people during this period. As for the baptized, their number grew up only up to 877 people. New centres of spreading Christianity appeared. These are Izynzhulsky, Tesinsky, Beisky parishes. Mixed parishes were also organized: by the end of the 1820-s the baptized Khakass people were in all 18 parishes of the KhakassMinusinsk region.

During the following 25 years the dynamics of the population number became positive. By 1861 there were $49,4 \%$ of baptized people in the total number of native inhabitants. By that time there were 40 parishes on the territory of the KhakassMinusinsk region. The baptized Khakass people lived in 24 of them. In the 1850-s the parishes with Khakass population only were organized. The Khakass people's concentration was observed in the following parishes: Bozhe-Ozersky, UstFyrkalsky, Novo-Mar'iasovsky, Ust'-Abakansky. The part of the Khakass population of mixed parishes assimilated, became settled or turned to the peasantry.

In historical literature there are no common views on what stage the missionary activity was in the $2^{\text {nd }}$ quarter of the XIX century. To answer the question whether it was the period of crisis or development it is necessary to define assessment criteria. The first parameter is quantitative. It shows the dynamics of the number of those who adopted Orthodoxy. The second parameter is qualitative. It shows how Christian ideas became stronger and ceremonies came to everyday life and ritual practice.

The number of the christened can be illustrated by the example of the vedomstvo (establishment) of the Steppe Duma of the united mixed tribes (Table 2).

In general, during 1827-1838 the number of the newly-baptized people increased by 7,5 $\%$, at the same time the process of some clans' deviation from Orthodoxy grew up to $25 \%$ (Kazanovsky). In the contemporaries' opinion, giving awards, incentives to governmental and clergy representatives and the newly-baptized themselves led to the fact that adopting Orthodoxy they were "completely incapable of the intelligent perception of the belief". The exemption from yasak (tribute) for three years resulted in repeated christening (Kuznetsova, Kulakov,

Table 1. The dynamics of the number of the newly-baptized Christians in the Khakass-Minusinsk region in the XVIII century -1861 .

\begin{tabular}{|l|c|c|c|c|c|}
\hline \multicolumn{1}{|c|}{ Khakass people } & \multicolumn{5}{c|}{ Year } \\
\cline { 2 - 6 } & 1768 & 1795 & 1823 г. & 1851 & 1861 \\
\hline People of both genders & 6112 & 16376 & 21182 & 23602 & 36179 \\
\hline The newly-baptized & 2400 & 5364 & 6241 & 7452 & 17877 \\
\hline $\begin{array}{l}\text { Percentage of the newly-baptized to the total } \\
\text { number }\end{array}$ & 39,2 & 32,7 & 29,46 & 31,57 & 49,4 \\
\hline
\end{tabular}


Table 2. The dynamics of the number of the newly-baptized Christians in 1827-1838 (according to the register of the Steppe Duma of the united mixed tribes)

\begin{tabular}{|l|c|c|}
\hline \multicolumn{1}{|c|}{ The Steppe Duma of the united mixed tribes } & $\begin{array}{c}\text { The percentage of the } \\
\text { baptized in \% }\end{array}$ & Dynamics (+) or (-) \\
\hline Beltyrsky & 46 & $-2,7$ \\
\hline Blizhnekarginsky & 57,4 & +11.7 \\
\hline Dal'nekarginsky & 48,4 & +4.7 \\
\hline Karachersky & 89,6 & $+35,8$ \\
\hline Kyzylsky & 35,8 & $+2,1$ \\
\hline Kiisky & 57,9 & $+29,8$ \\
\hline Kivinsky & 58,2 & $+8,6$ \\
\hline Kazanovsky & 24,6 & -25 \\
\hline Sagaisky $\left({ }^{\text {st }}\right.$ and $2^{\text {nd }}$ halves) & 33,29 & $-4,1 \%)$. \\
\hline $\begin{array}{l}\text { Total (according to the register of the Steppe Duma of the } \\
\text { united mixed tribes) }\end{array}$ & 50,1 & $+7,5$ \\
\hline
\end{tabular}

1898). According to confession records even the Russians (most probably Russian surnames) were among them. Having adopted Orthodoxy, the baptized Khakass people wore a crucifix on their neck; they had icons at home, but they neither got married in church nor performed funeral services, they neither made their confessions nor threw the things of shaman cult away. Children had got two names - a parental one and a Christian one, given when baptized.

Penetration of Christian ideas and ritual practice into everyday life is described by G.I. Spassky, a contemporary of those events: "The Sagai people have accepted the Christian law and are practising in tillage, but many of them are devoted to shamanism, the Beltyr people are fervent followers of ancient traditions and are stagnating in shamanism". He understood that "a foreign language opens the way to foreign customs and leads to the disappearance of the nation's independence". In his other work G.I. Spassky mentioned: "Since ancient times some nomadic peoples - especially the Sagai people - have accepted the Christian law, but only a few knew the simplest religious duties. All of them differ from the faithless, who live on the same territory, only in not eating horse meat" (Spassky, 1818).

In the Khakass-Minusinsk region almost all newly-baptized people were ascribed to village parishes. The priests were entrusted with the additional duties to affirm Orthodoxy in the neophytes. During the period of the XVIII-XIX centuries sermons were preached in Russian and Old (Church) Slavonic. The attempts to translate the Bible into the indigenous Siberian peoples' languages were episodic and ineffective. The Ust'-Yesinsky parish was the only one in the Yenisei Eparchy where the service was in the Khakass language. That parish was opened only in 1876 (with Nikolas Katanov, a priest, and Semen Chismochakov, a teacher). Later on S. Chismochakov became a priest of the Ust'Yesinsk Church and he got "three notebooks of printed hours (prayers) in a foreign language" from Makariy, a bishop of Tomsk and Barnaul. In 1887 the first ABC-book in the Shor language appeared. That year "The path to the Kingdom of Heaven", "The Holy story of the Old and the New Testaments" in the Khakass language "were presented to literate Nicolas and Stephan Kokov, then the committee sent 20 more copies". 
On account of traditional peculiarities of ethno-demographical, geographical and socioeconomic development, the newly-baptized people's parishes were larger than those in the central part of Russia. The parochial communities were the zones of socio-cultural interaction. In mixed communities Christian ideas and customs were adopted quicklier, the interchange of standard-value, behavioural and labour traditions took place. Thus, an objectively favourable background for Christianization was created. At the same time Russian peasants professed Orthodoxy and did not display any tolerance because of their pragmatism. Moreover, they took some ideas of shamanism. The Head of the Minusinsk region wrote in 1854: "A sensible shortcoming in the people is the remains of heathenism, a belief in wood goblins, mermaids; children organize witchcraft, everyone tells fortunes at Christmastide".

The state's active legislative work in the religious sphere, a strict control of the church and the government, a variety of forms and methods of Christianization resulted in the increase of the number and percentage of the newly-baptized people in the $2^{\text {nd }}$ half of the XIX century. But Christianization still remained formal. That's why by the end of the $50-\mathrm{s}-$ the beginning of the 60 -s of the XIX century the crisis of the missionary activity became obvious. The state authorities and clergy representatives, the direct executives of the religious policy, understood that fact. The clergy representatives saw the reasons of misfortune in the policy of tolerance, a weak financial and organizational support of the state, unpreparedness of the missionaries themselves. We suppose that the changes in a socio-political sphere were one of those reasons. Those changes concerned the equalization of the newly-baptized people with the state peasants regarding the tax. The transformation of tribal organizations of nonSiberians since 1822 into a legitimate structure of the local authority increased its opposition to the Orthodox mission.

Thus, the reduction of tempos of nonRussian nationalities' christening, the newlybaptized people's secession from Orthodoxy, their inobservance of Orthodox customs make it possible to conclude the missionary activity's stagnation in the $1^{\text {st }}$ quarter of the XIX century. In spite of a quantitative and relative increase of the newly-baptized people by 1861 , christening still remained formal. The established system of missionary activity could not solve the politicaland-ideological objectives of assimilation of the indigenous population of Siberia, integration of a multi-confessional multilingual space of the Russian Empire and was in need of cardinal changes.

In the XVIII-XIX centuries the religious policy evolved from intolerance to tolerance, keeping succession. The period from the last third of the XVIII century, when the principle of liberal attitude towards religion was established, is characterized by the decline of the missionary activity and the crisis by the beginning of the 60 -s of the XIX century. This period witnessed the institutionalization of the missionary activity, the establishment of the uniform system of the church-and-state institutions, exercising their control, the development of common principles of christening of the non-Russians of the Russian Empire as well as of legal and fiscal status of the newly christened.

\section{References}

1. Bykonia G.F. The Settlement of the Yenisei region by the Russians in the XVIII century. Novosibirsk, 1981. 248 p. 
2. Kuznetsova A., Kulakov P. The Minusinsk and Achinsk non-Russian people: materials for study (Part 3). Krasnoyarsk, the Yenisei Province Administration Publishing, 1898. 294 p.

3. Mavlutova G. The Missionary activity of the Russian Orthodox Church in the North-West Siberia (the XIX - the beginning of the XX centuries. Tyumen, the Tyumen State University Publishing, 2001. $177 \mathrm{p}$.

4. The report on the missionary activity in the Yenisei eparchy in 1887. (1888). The Yenisei eparchial vedomosti (journal), 8, 102-106.

5. Spassky G. The people roaming in the Upper Yenisei. The Siberian Bulletin. St. Petersburg, 1818.

\title{
List of abbreviations
}

$S A K K$ - The State Archives of Krasnoyarsk krai

$M S M A$ - Minusinsk State Municipal Archives

CSARK - The State Archives of the Republic of Khakassia

\section{К проблеме эволюции миссионерской деятельности \\ Русской православной церкви \\ в XVIII - 60-х гг. XIX в.}

\author{
В.Н. Асочакова \\ Хакасский государственный университет \\ им. Н.Ф. Катанова \\ Россия, 655016, Республика Хакасия, Абакан \\ ул. Дружбы народов, 18-133
}

\begin{abstract}
Христианизаџия коренных народов Сибири на протяжении двух столетий носила общий характер и опиралась на единую правовую основу. Государственные установки светских властей в отнотении аборигенов как подданных Российской империи характеризовались сдержанным отношением к массовым крещениям и веротерпимостью $к$ сложившимся религиозным верованиям автохтонов. Эти общие установки корректировались Русской православной церковью, структуры которой их реализовывали, а узковедомственные интересы диктовали ускоренные темпы христианизачии. В статье рассмотрены реформы миссионерской деятельности в XVIII - первой четверти XIX в., целью которых был переход от формального крещения к утверждению христианства и русификачия нерусских народов. На примере автохтонного населения Хакасско-Минусинского края проанализированы особенности форм, методов крещения и количественные показатели крещения. Источниковая база представлена делопроизводственной документацией и источниками иерковного демографического учета.
\end{abstract}

Ключевые слова: христианизация, Русская православная церковь, миссионерская деятельность, веротерпимость, новокрещеные.

Научная специальность: 07.00.00 - исторические науки. 